\title{
Recent changes to the Fundamentals of Engineering (FE) exam and ways engineering libraries can support students
}

\section{Ms. Jean L Bossart P.E., University of Florida}

Jean Bossart is an Associate Engineering Librarian at the University of Florida (UF). She assists students with research, data support, and citation management. She investigates and integrates creative technologies, such as 3D printing into the STEM discipline library services. She has a BS in chemical engineering and MS in environmental engineering from UF, over 20 years of experience in industry and consulting, and is a licensed professional engineer in Florida. 


\title{
Recent changes to the Fundamentals of Engineering (FE) exam and ways engineering libraries can support students
}

\author{
Jean L. Bossart, PE (University of Florida)
}

\begin{abstract}
The Fundamentals of Engineering (FE) exam, part one of a two-part licensure exam, has undergone significant changes in the last few years. This paper provides a pedagogical discussion of the recent changes to the FE exam, presents data on FE passing rates over the last five years, and discusses ways engineering libraries can support their students as they prepare to take the FE exam in their senior year. Earning licensure as a Professional Engineer (PE) is often the culmination of an engineering student's education and apprenticeship. But getting there can be difficult and sometimes confusing especially when the process changes. There are four requirements to becoming a PE: graduate from an ABET-accredited engineering program, pass the FE exam, work under a PE for three to four years, and pass the PE exam. Prior to 1996, all applicants took the same FE exam regardless of their engineering discipline. After 1996, the morning portion of the exam was the same for test takers but the afternoon exam was discipline specific. That changed again in 2014 and applicants now take the FE exam in one of seven disciplines: chemical, civil, electrical and computer, environmental, industrial and systems, mechanical, or other disciplines. Undergraduate engineering students may take the FE exam in their senior year. For many civil engineering seniors, passing the FE exam is a requirement for graduation and often a condition of employment. For other disciplines, the FE exam is optional but recommended for students interested in pursuing an engineering career where protection of public health and safety are of concern.
\end{abstract}

\section{Background/Literature Review}

Clean water, reliable energy, safe transportation, and life-saving medical equipment are just a few ways that engineers make the world better and safer for all of us. By law, only a licensed engineer may prepare, sign and seal, and submit engineering plans and drawings to a public authority for approval. Professional Engineers (PEs) bear the responsibility for not only their work, but also for the lives affected by that work and must hold themselves to high ethical standards of practice.

In the United States (U.S.), engineers are licensed by the state in which they practice. Wyoming was the first state to require licensure for engineers. As more states enacted similar legislation, a need arose for uniformity of laws and requirements. In 1920, the National Council of Examiners for Engineering and Surveying (NCEES), a nonprofit organization, was created to advance licensure and facilitate mobility among the licensing jurisdictions. In 2020, the NCEES is celebrating its 100 th anniversary [1].

Engineers are responsible for the lives affected by their work and must hold themselves to high ethical standards of practice. Engineering students learn about professionalism through their university course work and from other engineers [2]. Students learn that an engineer's 
professional responsibilities include protection of the public and the environment. Students need an understanding of the potential risks resulting from their work. Public safety and environmental protection must be at the forefront of their engineering work [3].

The Accreditation Board for Engineering and Technology, Inc. (ABET) is a non-governmental organization that accredits post-secondary education programs. ABET accreditation is proof that a collegiate program meets standards essential for producing graduates ready to enter the engineering workforce [4]. Although there are some slight variations by state, there are four major requirements to becoming a professional engineer $(\mathrm{PE})$ :

- Graduate from an ABET-accredited engineering program,

- Pass the Fundamentals of Engineering (FE) exam,

- Work under a PE for four years (three years with a Master's in engineering), and

- Pass the PE exam.

Undergraduate engineering students may take the FE exam prior to graduation in their senior year [5]. During an engineering student's senior year, their time is limited and occupied with senior design projects, finishing course work, and job hunting. Studying for the FE exam is often the last thing on their minds. However, their interest increases when they learn that being able to list on their resume that they passed the FE exam may increase their chances of getting a job after graduation [6]. Passing the FE can be a differentiator for some employers. When hiring, companies typically make decisions based upon which candidate they believe will bring the most benefit to their company. Having a choice between two qualified applicants, one with an FE working towards a PE license or one without, an employer will often choose the candidate who brings the most to the table.

An article by Jason Kent, PE, "The Power of the PE License", outlines some compelling reasons on why students should consider pursuing PE licensure [7]. Only a PE can sign and seal engineering plans and drawings. This is important whether the engineer works in the public or private sector. Accordingly, PEs accrue more workplace responsibility and this leads to promotions and higher pay. Licensure for a consulting engineer or a private practitioner is not something that is merely desirable; it is a legal requirement for those who are in responsible charge of work. Other incentives are that once a student earns their FE, it is transferable to any other state in the U.S. This is important since students don't often know where they may get their first job. The minimum registration requirements are standardized nationally. The student would have to register with the board of engineering in their new state, but they would not have to retake the FE exam. Of most interest to students is that PEs earn higher salaries than non-PEs. According to a 2019 article based on a survey by the American Society of Civil Engineers, engineers with a PE license earn about $20 \%$ more than non-licensed engineers [8].

A point of contention with many engineers is the question of whether an individual can officially call themselves an engineer unless they are licensed. On business cards, letterheads, and resumes, some states say that only PEs can identify themselves as an engineer. The National Society of Professional Engineers (NSPE) which was established in 1934, agrees that "Licensure is the mark of a professional. It's a standard recognized by employers and their clients, by governments and by the public as an assurance of dedication, skill and quality" [9]. 


\section{Purpose}

There have been numerous changes to the FE exam, some as recent as 2017 and 2018. The purpose of this paper is to:

- Summarize the changes to the FE exam

- Present data on FE passing rates by discipline

- Discuss FE exam trends since the changes were introduced

- Suggest ways engineering libraries can support their senior engineering students as they prepare to take the FE exam

\section{Changes to the FE Exam}

The FE exam was first offered in 1965 and through 1996 all students took the same 8-hour exam regardless of their engineering discipline [1]. After 1996, while the four-hour morning portion of the exam remained the same for all applicants, a discipline specific afternoon session was added for civil, mechanical, electrical, industrial, chemical or general, later known as "other disciplines". Environmental engineering was added in 2002, bringing the total tested disciplines to seven. Until 2014, the FE was a pencil-and-paper test consisting of 180 multiple choice questions offered only twice per year and taking approximately six weeks to report scores. In 2014, however, the FE test transitioned to a computer-based format, which allowed the test to be offered year-round. In addition, the number of test questions was reduced from 180 to 110 , which shortened the test from a grueling eight hours to less than six hours and scores are released in seven to ten days [10]. At this time the test also transitioned to discipline specific for both the morning and afternoon portions, each with approximately 55 questions including those common to all tests in the subjects of mathematics, probability and statistics, ethics and professional practice, and engineering economics [5]. Figure 1 shows a timeline which summarizes the major changes to the FE exam.

The computer-based FE exam is administered through Pearson Vue test centers (during four testing windows: Jan-Feb, Apr-May, Jul-Aug, Oct-Nov), which maintains hundreds of NCEESapproved test centers both in the U.S. and at international locations [5]. Starting in 2017, the computer-based FE introduced a new testing component called alternative item types (AITs), which are questions other than traditional multiple-choice questions [11]. In 2018, the examination fee was reduced from $\$ 225$ to $\$ 175$ [5].

The only reference material that may be used is a handbook which is issued to examinees in the morning; it must be left in the room after each session. For study purposes, this handbook may be obtained by downloading from the NCEES website (http://ncees.org/exams/exampreparation-materials/ or by purchasing a hard copy. However, examinees may not bring their own copies to the test site; they must use the ones issued to them by the proctors and may not write in them [5]. 
1965

FE exam first administered,

same exam

for all

applicants
1996

Morning exam

same for all;

afternoon exam

becomes

discipline

specific
2014

FE transitions to computer based format and becomes 7 freestanding, discipline-specific exams

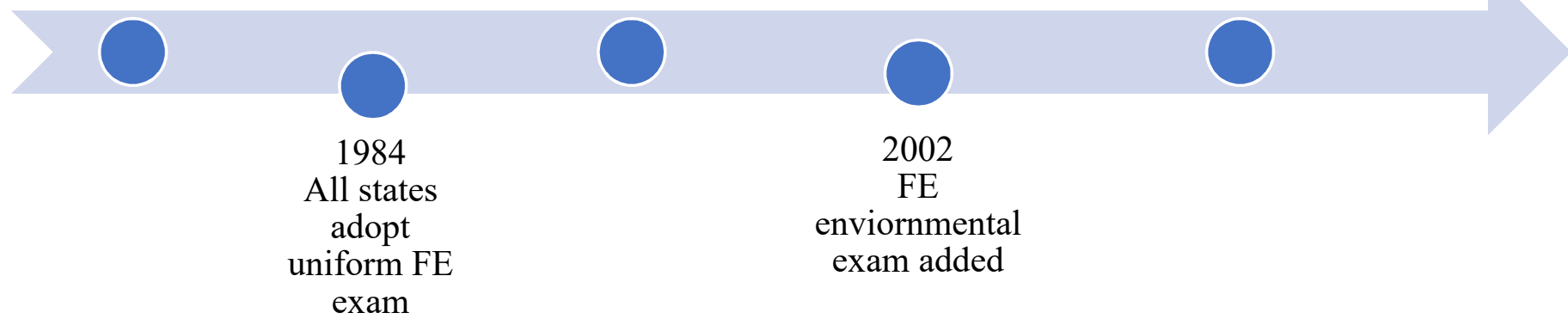

Figure 1. FE exam milestones [1].

\section{FE Passing Rates}

In 2019, 40,111 engineering students across the U.S. took the FE exam for the first time [5]. A scaled score of 70 is needed to pass. Once an individual passes the FE exam and they graduate with their bachelor's degree in engineering, they then can apply to their state to receive an engineer intern (EI) certificate, sometimes referred to as an engineer-in-training (EIT).

As shown in Table 1, the passing rates for students taking the test within 12 months of graduation are fairly consistent over the five-year periods from 2015-2019 [12-16]. In 2019, passing rates ranged from $60 \%$ for industrial and systems engineers to $76 \%$ for environmental engineers. Civil and mechanical engineering students are the predominant groups who take the exam, followed by electrical engineering majors.

Table 1. Passing rates for the FE exam first time test takers 2015-2019.

\begin{tabular}{|l|c|c|c|c|c|c|c|c|c|c|}
\hline \multirow{2}{*}{ Discipline } & \multicolumn{2}{|c|}{$\mathbf{2 0 1 9}$} & \multicolumn{2}{c|}{$\mathbf{2 0 1 8}$} & \multicolumn{2}{c|}{$\mathbf{2 0 1 7}$} & \multicolumn{2}{c|}{$\mathbf{2 0 1 6}$} & \multicolumn{2}{c|}{$\mathbf{2 0 1 5}$} \\
\cline { 2 - 11 } & Exams & Pass & Exams & Pass & Exams & Pass & Exams & Pass & Exams & Pass \\
\hline Chemical & 2,447 & $75 \%$ & 2,337 & $73 \%$ & 2,274 & $74 \%$ & 2,389 & $76 \%$ & 2,014 & $76 \%$ \\
\hline Civil & 15,473 & $65 \%$ & 14,407 & $65 \%$ & 13,770 & $65 \%$ & 13,089 & $67 \%$ & 11,693 & $67 \%$ \\
\hline Electrical & 5,041 & $64 \%$ & 4,703 & $65 \%$ & 4,755 & $67 \%$ & 4,295 & $68 \%$ & 3,629 & $70 \%$ \\
\hline Environ. & 2,159 & $76 \%$ & 2,048 & $76 \%$ & 1,932 & $75 \%$ & 1,814 & $75 \%$ & 1,613 & $76 \%$ \\
\hline Industrial & 666 & $60 \%$ & 598 & $61 \%$ & 606 & $66 \%$ & 510 & $62 \%$ & 463 & $64 \%$ \\
\hline Mechanical & 11,018 & $75 \%$ & 10,750 & $76 \%$ & 9,817 & $75 \%$ & 9,295 & $77 \%$ & 8,140 & $80 \%$ \\
\hline Other & 3,307 & $72 \%$ & 3,321 & $73 \%$ & 3,744 & $73 \%$ & 3,806 & $76 \%$ & 3,562 & $78 \%$ \\
\hline Total & $\mathbf{4 0 , 1 1 1}$ & $\mathbf{3 6 , 1 6 4}$ & $\mathbf{3 6 , 8 9 8}$ & $\mathbf{3 5 , 1 9 8}$ & & $\mathbf{3 1 , 1 1 4}$ & \\
\hline
\end{tabular}

Sources: [12-16]

During 2019, 3,307 engineering students across the U.S. took the FE "other discipline" exam for the first time. Table 2 provides a breakdown of the engineering degrees (seeking or awarded) to the students taking the "other discipline" FE exam in the first six months of 2019 and the second 
six months of 2019. Most of the undergraduate degrees for these "other discipline" test takers were in biological engineering, followed by general engineering, architectural engineering, and petroleum engineering [5].

Table 2. FE "Other disciplines" Passing rates and number of first-time test takers between January and June 2019 and July and December 2019.

\begin{tabular}{|l|c|c|c|c|}
\hline \multirow{2}{*}{ Program } & \multicolumn{2}{|c|}{ Jan-Jun 2019 } & \multicolumn{2}{c|}{ Jul-Dec 2019 } \\
\cline { 2 - 5 } & $\begin{array}{c}\text { Number of } \\
\text { Test Takers }\end{array}$ & $\begin{array}{c}\text { Pass } \\
\text { Rate }\end{array}$ & $\begin{array}{c}\text { Number of } \\
\text { Test Takers }\end{array}$ & $\begin{array}{c}\text { Pass } \\
\text { Rate }\end{array}$ \\
\hline Agricultural & 66 & $89 \%$ & 38 & $84 \%$ \\
\hline Architectural & 134 & $73 \%$ & 58 & $71 \%$ \\
\hline Biological (not Bio-Medical) & 208 & $82 \%$ & 101 & $80 \%$ \\
\hline Civil & 25 & $80 \%$ & $<25$ & - \\
\hline Engineering Physics/Engineering Science & 47 & $83 \%$ & $<25$ & - \\
\hline General Engineering & 148 & $82 \%$ & 49 & $76 \%$ \\
\hline Geological and Geophysical & 38 & $61 \%$ & $<25$ & - \\
\hline Materials & 38 & $74 \%$ & $<25$ & - \\
\hline Mechanical & 76 & $82 \%$ & 66 & $89 \%$ \\
\hline Mining/Mineral & 65 & $48 \%$ & $<25$ & - \\
\hline Naval Architecture and Marine & 48 & $92 \%$ & 46 & $80 \%$ \\
\hline Nuclear & 60 & $90 \%$ & $<25$ & - \\
\hline Petroleum & 132 & $67 \%$ & 56 & $52 \%$ \\
\hline
\end{tabular}

Note: Only EAC/ABET degrees with more than 25 first-time examinees are reported.

Source: [5]

Many colleges and universities require their civil engineering students to pass the FE exam as a condition for graduation. Other colleges encourage their students to take the FE during their senior year but do not make passing a graduation requirement. Table 3 shows the top ten universities who had the most first-time FE examinees in 2019.

Table 3: Institutions which have the largest number of first-time FE examinees in 2019.

\begin{tabular}{|l|c|}
\hline Institution & $\begin{array}{c}\text { Number of first time FE } \\
\text { examinees in 2019 }\end{array}$ \\
\hline Missouri University of Science and Technology & 683 \\
\hline Texas A\&M University & 550 \\
\hline Montana State University & 476 \\
\hline University of Colorado & 417 \\
\hline California State Polytechnic University, San Luis Obispo & 397 \\
\hline North Carolina State University & 378 \\
\hline Penn State University & 373 \\
\hline Washington State University & 366 \\
\hline University of Nevada, Reno & 347 \\
\hline U.S. Military Academy & 346 \\
\hline
\end{tabular}

Source: [12] 


\section{FE Exam Trends and Assessment}

The number of students taking the FE exam declined slightly when the test went from being offered twice a year to being offered year-round at the test centers. It has been speculated that students procrastinate in studying and sitting for the exam since there are no set test dates [10].

The FE exam results can be used as an outcome assessment tool for engineering schools and their departments. For assessment purposes, the focus of the exam is on performance in specific subjects rather than overall passing rates. An engineering program that requires all of their students to take the exam but not necessarily pass the exam to graduate can use the exam results as an assessment tool for evaluating their curriculum [17]. As engineering schools evaluate their academic programs in reference to other programs, the FE exam results can be used as one measurement in the assessment of at least three of the seven student outcomes included in ABET General Criterion 3:

Outcome 1 - an ability to identify, formulate, and solve complex engineering problems by applying principles of engineering, science, and mathematics;

Outcome 2 - an ability to apply engineering design to produce solutions that meet specified needs with consideration of public health, safety, and welfare, as well as global, cultural, social, environmental, and economic factors; and

Outcome 4 - an ability to recognize ethical and professional responsibilities in engineering situations and make informed judgments, which must consider the impact of engineering solutions in global, economic, environmental, and societal contexts [18].

The NCEES offers institutions free reports that breakdown the performance of their students on the FE exam. Institutions can use this information to evaluate their departments over time, revising curriculums as necessary, and compare their institution's passing rates to those of their peer institutions.

\section{Role of Engineering Libraries}

Preparing for the FE exam can be a time-consuming activity when senior engineering students are busy with their senior design projects and job searches. Engineering libraries can help their students by:

- Making a LibGuide that includes links to their state's resources and NCEES exam guides and other useful information. The NCEES Examinee Guide is the official guide to policies and procedures for all NCEES exams. All examinees are required to read this document before starting the exam registration process [19]. Although students are used to taking tests by their senior year, the FE exam has unique features. Videos are one method that students can use to familiarize themselves with these features: https://www.youtube.com/playlist?list=PLiZ0hjHNi9jzR8RW69ndkjIgH8bzj0ew

- Adding the latest FE review manuals to their collections. With the discipline specific changes to the FE exam, the review manuals also changed. Older review manuals may be 
helpful for the general subject areas, but manuals issued after 2014 have the most up-todate question format. There are many review manuals and practice exams available but those by Michael R. Lindeburg, PE are the most widely used. As of 2019, five FE review manuals have been published by Professional Publications, Inc. which is the best-selling publisher of review manuals:

- FE Chemical Engineering Review Manual (2016) ISBN 9781591264453

- FE Civil Engineering Review Manual (2014) ISBN 9781591264392

- FE Electrical and Computer Engineering Review Manual (2015) ISBN 9781591264491

- FE Mechanical Engineering Review Manual (2014) ISBN 9781591264415

- FE Other Engineering Disciplines Review Manual (2014) ISBN 9781591264439

- Offering workshops on navigating the FE exam application process and tips for reducing the cost of taking the exam. The expense of preparing and taking the exam can be a barrier for some engineering students. So much so that the NCEES reduced the FE test fee from $\$ 225$ to $\$ 175$ in 2018 . The state where a student takes the exam may also have additional fees which can be $\$ 100$ or more. In library workshops, students can learn cost saving tips. For example, in Florida, students who directly register with NCEES pay an additional cost of $\$ 100$. However, for a student who applies with the Florida Board of Professional Engineers (FBPE) prior to registering for the FE exam, the additional cost is only $\$ 30$, a savings of $\$ 70[20]$.

- Hosting review sessions for the exam. Students who take a review class can improve their chances of passing. However, review courses offered through vendors can be expensive, up to $\$ 1,600$ [21]. Academic libraries can host review courses and ask their engineering faculty to teach one hour reviews in their subject specialization. Graduate engineering students are also a good resource to teach general subject matter reviews such as mathematics, statistics, and engineering economics, which are common to all the FE exams.

- Purchasing and making "approved" calculators available for check out to students. Students are allowed only certain calculator models in the exam. These calculators are non-programmable, and many students do not own them. It is important to do the practice exams using only a calculator from the approved calculator list so that the students become familiar with the functions of the approved calculators. Libraries can purchase these calculators and make them available to students for check-out. Students can then decide which of the approved calculators is best for their needs. The following is the current NCEES approved calculator list [22]:

- Casio: All fx-115 and fx-991 models (Any Casio calculator must have "fx-115" or "fx991" in its model name.)

- Hewlett Packard: The HP 33s and HP 35s models, but no others

- Texas Instruments: All TI-30X and TI-36X models (Any Texas Instruments calculator must have "TI-30X" or "TI-36X" in its model name.) 
- Inviting engineers to speak at the library on their experiences as PEs. When students hear of the rewarding career opportunities a PE license can afford them, they become more motivated to pursue licensure. Inviting professional engineers to speak on their experiences is a powerful way for students to hear first-hand from an accomplished professional engineer. University alumni are often eager to share their insights with the next generation of engineers.

\section{Conclusions}

There have been significant changes to the FE exam since 2014. The biggest changes have been that the FE exam is now discipline specific and administered year-round at testing centers throughout the U.S. Engineering libraries can assist their senior engineering students to navigate the road to becoming professional engineers by preparing a LibGuide with up-to-date information, adding discipline specific review manuals to their collections, offering workshops to aid students with the application process, hosting review sessions, offering approved calculators for check-out, and inviting professional engineers to speak at the library. It is important that students learn about the resources available to them and the benefits of starting in their senior year to achieve this level of professional development.

\section{References}

[1] National Council of Examiners for Engineering and Surveying (NCEES), History. [Online]. Available: https://ncees.org/history/. [Accessed Nov. 18, 2019].

[2] M.C. Loui, "Ethics and the development of professional identities of engineering students," Journal of Engineering Education, vol. 94(4), pp. 383-390. Oct. 2005.

[3] S. Sheppard, K. Macatangay, A. Colby, and W. Sullivan, Educating Engineers: Designing for the Future of the Field. San Francisco: Jossey-Bass, 2009.

[4] Accreditation Board for Engineering and Technology, Inc., Why ABET accreditation matters. [Online]. Available: https://www.abet.org/accreditation/what-is-accreditation/whyabet-accreditation-matters/. [Accessed Nov. 27, 2019].

[5] NCEES, FE exam. [Online]. Available: https://ncees.org/engineering/fe/. [Accessed Nov. 18, 2019].

[6] S.M. Palmquist, "Professional practice: Teaching the value of licensure," in American Society for Engineering Education (ASEE) Zone 2 Spring Conference Proceedings (Vol. 6), San Juan, Puerto Rico, Mar. 2-5, 2017.

[7] J. Kent, The Power of the PE License. [Online]. Available: https://www.monster.com/career-advice/article/professional-engineer-license-pe. [Accessed Nov. 18, 2019].

[8] American Society of Civil Engineers (ASCE). Civil engineers' income rises faster than national average. [Online]. Available: https://www.asce.org/templates/press-releasedetail.aspx?id=32866. [Accessed Sep. 11, 2019].

[9] National Society of Professional Engineers (NSPE). Why get licensed? [Online]. Available: https://www.nspe.org/resources/licensure/why-get-licensed. [Accessed Jan. 15, 2020].

[10] E. Kaplan-Leiserson,"The evolution of the FE", PE Magazine, March 2015. [Online]. Available: https://www.nspe.org/resources/pe-magazine/march-2015/the-evolution-the-fe. [Accessed Jan. 15, 2020]. 
[11] NCEES, NCEES exams transition to computer-based testing (CBT). [Online]. Available: https://ncees.org/exams/cbt/. [Accessed Nov. 18, 2019].

[12] NCEES, NCEES 2019 Squared: A year in the numbers. [Online]. Available: https://ncees.org/about/publications/past-annual-reports-squared/. [Accessed March 6, 2020].

[13] NCEES, NCEES 2018 Squared: A year in the numbers. [Online]. Available: https://ncees.org/about/publications/past-annual-reports-squared/. [Accessed Jan. 15, 2020].

[14] NCEES, NCEES 2017 Squared: A year in the numbers. [Online]. Available: https://ncees.org/about/publications/past-annual-reports-squared/. [Accessed Jan. 15, 2020].

[15] NCEES. 2017. NCEES 2016 Squared: A year in the numbers. [Online]. Available: https://ncees.org/about/publications/past-annual-reports-squared/. [Accessed Jan. 15, 2020].

[16] NCEES. 2016. NCEES 2015 Squared: A year in the numbers. [Online]. Available: https://ncees.org/about/publications/past-annual-reports-squared/. [Accessed Jan. 15, 2020].

[17] G.C. Crawford, J.W. Steadman, D.L. Whitman, and R.K. Young, "Using the Fundamentals of Engineering (FE) exam as an outcomes assessment tool", NCEES. [Online]. Available: https://ncees.org/wp-content/uploads/FEOAT-white-paper-2019.pdf [Accessed Jan. 19, 2020].

[18] ABET Engineering Accreditation Commission. "Criteria for accrediting engineering programs, 2019-2020". [Online]. Available: https://www.abet.org/accreditation/accreditation-criteria/criteria-for-accreditingengineering-programs-2019-2020/. [Accessed Jan. 19, 2020].

[19] NCEES, Examinee Guide. [Online]. Available: https://ncees.org/exams/examinee-guide/. [Accessed Jan. 19, 2020].

[20] Florida Board of Professional Engineers. Engineering Exams. [Online]. Available: https://fbpe.org/licensure/licensure-process/engineering-exams/. [Accessed Jan. 19, 2020].

[21] Testing.org, A comprehensive guide to FE exam prep courses in 2020. [Online]. Available: https://testing.org/best-fe-exam-prep-courses/. [Accessed Jan. 19, 2020].

[22] NCEES, Calculator policy. [Online]. Available: https://ncees.org/exams/calculator/. [Accessed Jan. 21, 2020]. 